\title{
A Corpus-Based Model of the English Phrasal Verb Construction: Attraction
}

\author{
Ekaterina Golubkova \\ Moscow State Linguistic University \\ Chaikina street, dom 6, kv. 150 \\ 125315 Moscow \\ The Russian Federation \\ katemg@yandex.ru
}

\author{
Alexander Trubochkin \\ Moscow State Linguistic University \\ Bibliotechnaya street, dom 16, kv. 12 \\ 141406 Moscow oblast, Khimki, \\ The Russian Federation \\ nalugu@mail.ru
}

\begin{abstract}
The article investigates the semantic of English phrasal verbs $(\mathrm{PhVs})$ which are viewed as lexico-grammatical constructions. Triangulation of introspective, cognitive and corpus methods of analysis allows us to identify the semantic dimensions which feature the semantic pattern of the PhV-construction. The construction reveals the features of attraction involving new verbs provided the action or motion event is identical. Depending on the attraction strength level between the verb and the particle a new verb may be accepted to fill in the corresponding slot of the construction, which gives rise to a new phrasal verb. It allows us to categorise PhVs according to the attraction level and spot their $\mathrm{PhV}$-patterns on corpus data.
\end{abstract}

Keywords: attraction; corpus data; phrasal verbs; construction

DOI: $10.28995 / 2075-7182-2021-20-278-288$

\section{Корпусно-когнитивное моделирование семантики фразово-глагольной конструкции: аттракция}

\author{
Голубкова Екатерина \\ Московский государственный \\ лингвистический университет \\ 125315, Россия, г. Москва, \\ ул. Чайкина, д. 6, кв. 150 \\ katemg@yandex.ru
}

\author{
Трубочкин Александр \\ Московский государственный \\ лингвистический университет \\ 141406, Россия, Московская область, \\ г. Химки, ул. Библиотечная, д. 16, кв. 12 \\ nalugu@mail.ru
}

\begin{abstract}
Аннотация
В статье рассматривается семантика фразовых глаголов в составе лексико-грамматических конструкций. Триангуляция методов интроспективного, корпусного и когнитивного анализов позволяет установить семантические характеристики фразово-глагольной конструкции. Конструкция обладает свойством аналогической аттракции, допускающей в орбиту конструкции новые лексические единицы. В зависимости от уровня аттракции между глаголом и частицей, определяемой через анализ корпусных данных, новый глагол может заполнять соответствующий слот фразово-глагольной конструкции, образуя новую единицу номинации в языке.

Ключевые слова: аттракция; корпусные данные; фразовые глаголы; конструкция
\end{abstract}

\section{Introduction}

According to the viewpoints of different researchers, the phrasal verb $(\mathrm{PhV})$ is an indivisible linguistic unit with a certain structure. From this perspective, in line with a basic tenet of the theory of Construction Grammar, namely, that constructions are form-meaning pairings [3], so the meaning of construction 
cannot be formed compositionally but is shaped by the interaction of semantics and grammar, we assume that the phrasal verb can be viewed as a construction, too.

The aim of the current research is to define characteristic features of the phrasal verb construction (PhV-construction) and to determine the leading factors due to which the semantics of the phrasal verb construction can change. To this effect, we argue that this semantic change is linked to a variable, which we call 'attraction strength' [1], which can be defined as the ability to collocate and, specifically for new verbs, to be accepted by the construction to fill in the corresponding slot specifying the integrity and the unambiguity of the construction represented by the phrasal verb.

Another task of this research is to investigate the semantic behavioural pattern of phrasal verbs that can establish interconnectedness between the elements of the phrasal verb construction by measuring and examining the attraction strength.

The statistical basis of the research was: The BNC [10] and The Intelligent Web-based Corpus iWEB [11]. The experimental base was the phrasal verb cluster 'Leaving' ( 45 phrasal verbs) with the particle out taken from Longman phrasal verb dictionary [8]. The methods used to conduct the following measurements are: the collexeme analysis [4], the polynomial approximation of the result data which is used to describe alternately ascending and descending values for the analysis of a sizeable dataset of an unstable value.

\section{Attraction strength in phrasal verb constructions}

\subsection{Initial data}

To start the analysis of the functioning of a phrasal verb construction, we will turn to one of the clusters in the segment of phrasal verbs accompanying the particle out, namely, the cluster 'Leaving' of 45 phrasal verbs displayed in Tables 1 and 2, and try to reveal some semantic dimensions of an action associated with the phrasal verb construction based on empirical data assigned to the amount of contribution of the agent to perform an action, where three degrees of intensity are singled out: low contribution $=1$, average contribution $=2$, high contribution $=3$.

The intensity is the empirical quantitative parameter which specifies semantic dimensions of action based on the data retrieved from the BNC [10] and represents the semantics of phrasal verbs. Table 1 indicates a random distribution of the degree of intensity of the semantic dimensions of action (manner, strain, speed, duration, intention, morality, physicality, reversibility etc.) among the phrasal verbs under analysis. The classification of manner adverbs and the semantic dimensions is based on the offline introspection analysis [7] involving a native English speaker from the UK in the experiment. After Talmy we assume that the component of manner of action in phrasal verbs is likely to be expressed within the verb itself. We added a few semantic dimensions to the general concept of manner, relying on the poll taken with the native speaker of English, and placed them in the table header with a view to indicate the intensity of each semantic dimension corresponding to each test phrasal verb. Thus, Table 1 prototypes the semantics of the phrasal verbs in a digital manner, which we call 'the semantic matrix' of a phrasal verb cluster.

In order to uncover the possible regularity of change of contribution of the semantic dimensions depicted in Table 1, we research the behaviour pattern of the phrasal verbs using the collexeme method of analysis [2].

\subsection{Attraction of verbs to the 'Verb+out' construction using collexeme analysis}

In order to measure attraction, we apply the collexeme analysis to estimating the attraction of the verb (and the particle further) attracted by the slots of the construction. The collexeme analysis that deals with indivisible items such as lexemes appears to be applicable to our task because, from the viewpoint of Construction Grammar, constructions are already inseparable units, which enable us to substitute them for lexemes in the co-lexeme analysis. Moreover, the algorithm of co-lexeme analysis is not mathematically cumbersome and consists in probability calculation and comparison of the probability of success (positive outcome) of a certain word form of a certain lexeme in the corpus with the threshold value that is defined as the probability of success of the corresponding word form of all the lexemes of the same part of speech in the corpus. In terms of Construction Grammar, it comes to the calculation of 
the probability of success ${ }^{1}$ of a certain phrasal verb construction in the corpus compared to the threshold value that is defined as the probability of success of the Verb+out construction, in other words, the probability of success of all the analogous constructions in the corpus. Having compared these two values, we get the value of attraction. Thus, the collexeme analysis is chosen as the most convenient method for our research.

\begin{tabular}{|c|c|c|c|c|c|c|c|c|c|c|c|}
\hline \multicolumn{2}{|c|}{ Phrasal verb } & \multicolumn{10}{|c|}{ Semantic dimensions (aspects of action) } \\
\hline Verb & $\begin{array}{l}\text { Parti } \\
\text { cle }\end{array}$ & Manner & $\begin{array}{l}\text { Strain } \\
\text { 1- low } \\
\text { 2- avr, } \\
\text { 3- high }\end{array}$ & $\begin{array}{l}\text { Speed } \\
\text { 1- low } \\
\text { 2- avr. } \\
\text { 3- high }\end{array}$ & \begin{tabular}{|l|} 
Duration \\
1- low \\
2- avr. \\
3- high \\
\end{tabular} & $\begin{array}{l}\text { Intention } \\
\text { 1- unint. } \\
\text { 2- hesitat. } \\
\text { 3- intent. }\end{array}$ & \begin{tabular}{l}
\multicolumn{1}{c}{ Morality } \\
1- immoral \\
2- suspect \\
3- moral
\end{tabular} & \begin{tabular}{|l|} 
Physicality \\
1- nearly 0 \\
2- limited \\
3- real \\
\end{tabular} & $\begin{array}{l}\text { Reversibility } \\
\text { 1- irrevers. } \\
\text { 2- partially } \\
\text { 3- reversable }\end{array}$ & $\begin{array}{c}\text { Toolability } \\
1 \text { - toolless } \\
\text { 2- auxilary } \\
\text { 3- toolfull }\end{array}$ & $\begin{array}{l}\text { Agents } \\
\text { 1- one } \\
\text { 2- a few } \\
\text { 3- a lot }\end{array}$ \\
\hline allow & out & Controlled & 1 & 3 & 1 & 2 & 2 & 3 & 3 & 1 & 1 \\
\hline back & out & Renegade & 2 & 3 & 3 & 3 & 1 & 1 & 2 & 2 & 1 \\
\hline bail & out & Forceful & 3 & 3 & 1 & 3 & 3 & 3 & 1 & 3 & 1 \\
\hline break & out & Challenging & 3 & 3 & 1 & 3 & 1 & 1 & 3 & 2 & 1 \\
\hline breeze & out & Lightharted & 1 & 3 & 1 & 3 & 2 & 3 & 3 & 1 & 1 \\
\hline bug & out & Disorderly & 3 & 3 & 1 & 3 & 2 & 3 & 1 & 1 & 1 \\
\hline bust & out & Secretive & 3 & 3 & 1 & 3 & 1 & 3 & 1 & 2 & 1 \\
\hline buy & out & Gentle force & 2 & 3 & 3 & 3 & 2 & 1 & 1 & 2 & 1 \\
\hline coax & out & Careful & 1 & 1 & 3 & 3 & 2 & 3 & 3 & 1 & 1 \\
\hline check & out & Orderly & 1 & 3 & 1 & 3 & 3 & 2 & 3 & 3 & 1 \\
\hline clear & out & Forceful & 2 & 3 & 1 & 3 & 2 & 3 & 3 & 2 & 1 \\
\hline clock & out & Orderly & 1 & 3 & 1 & 3 & 3 & 2 & 3 & 3 & 1 \\
\hline come & out & Neutral & 2 & 2 & 2 & 3 & 2 & 3 & 3 & 1 & 1 \\
\hline draw & out & Careful & 1 & 1 & 3 & 3 & 2 & 3 & 3 & 1 & 1 \\
\hline duck & out & Secretive & 3 & 3 & 1 & 3 & 1 & 1 & 1 & 1 & 1 \\
\hline encourage & out & Careful & 1 & 1 & 3 & 3 & 2 & 3 & 3 & 1 & 1 \\
\hline fall & out & Accidental & 1 & 3 & 1 & 1 & 2 & 3 & 3 & 1 & 1 \\
\hline fly & out & Forceful & 3 & 3 & 1 & 2 & 2 & 3 & 3 & 1 & 1 \\
\hline get & out & Neutral & 2 & 3 & 2 & 3 & 2 & 1 & 3 & 1 & 1 \\
\hline go & out & Neutral & 2 & 3 & 2 & 3 & 2 & 3 & 3 & 1 & 1 \\
\hline let & out & Controlled & 1 & 3 & 1 & 2 & 2 & 3 & 3 & 1 & 1 \\
\hline light & out & Disorderly & 2 & 3 & 1 & 3 & 2 & 3 & 3 & 1 & 1 \\
\hline $\log$ & out & Orderly & 1 & 3 & 1 & 3 & 2 & 1 & 3 & 3 & 1 \\
\hline move & out & Orderly & 1 & 1 & 3 & 3 & 2 & 3 & 3 & 1 & 1 \\
\hline pile & out & Disorderly & 3 & 2 & 2 & 2 & 2 & 3 & 3 & 1 & 3 \\
\hline pop & out & Sudden & 2 & 3 & 1 & 1 & 2 & 3 & 3 & 1 & 3 \\
\hline pour & out & Controlled & 2 & 2 & 2 & 3 & 2 & 3 & 3 & 1 & 3 \\
\hline pull & out & Controlled & 3 & 1 & 2 & 3 & 2 & 1 & 3 & 1 & 1 \\
\hline punch & out & Desperate & 3 & 1 & 2 & 3 & 2 & 2 & 1 & 1 & 1 \\
\hline put & out & Forceful & 3 & 3 & 1 & 3 & 1 & 3 & 3 & 1 & 1 \\
\hline run & out & Desperate & 3 & 3 & 1 & 3 & 1 & 3 & 2 & 1 & 1 \\
\hline sally & out & Agressive & 3 & 3 & 1 & 3 & 2 & 3 & 1 & 1 & 3 \\
\hline see & out & Respectful & 1 & 2 & 2 & 3 & 3 & 3 & 1 & 1 & 1 \\
\hline set & out & Orderly & 1 & 3 & 1 & 3 & 2 & 3 & 3 & 1 & 1 \\
\hline ship & out & Specific & 1 & 1 & 2 & 3 & 2 & 3 & 1 & 3 & 1 \\
\hline shoot & out & Sudden & 3 & 3 & 1 & 2 & 2 & 3 & 3 & 1 & 1 \\
\hline show & out & Friendly & 1 & 2 & 2 & 3 & 3 & 3 & 1 & 1 & 1 \\
\hline sign & out & Orderly & 1 & 1 & 1 & 3 & 2 & 1 & 3 & 3 & 1 \\
\hline slip & out & Secretive & 2 & 1 & 2 & 3 & 1 & 3 & 3 & 1 & 1 \\
\hline spill & out & Uncontrolled & 3 & 2 & 3 & 1 & 2 & 3 & 1 & 1 & 3 \\
\hline start & out & Orderly & 1 & 3 & 2 & 3 & 2 & 2 & 3 & 1 & 1 \\
\hline step & out & Orderly & 2 & 3 & 2 & 1 & 2 & 3 & 3 & 1 & 1 \\
\hline storm & out & Agressive & 3 & 1 & 2 & 3 & 1 & 3 & 1 & 1 & 1 \\
\hline strike & out & Decisive & 2 & 3 & 1 & 3 & 2 & 2 & 3 & 3 & 1 \\
\hline want & out & Reluctant & 1 & 1 & 2 & 3 & 2 & 1 & 3 & 1 & 1 \\
\hline
\end{tabular}

Table 1: A random distribution of 45 phrasal verbs in cluster 'Leaving' and the values of intensity of their semantic dimensions (the semantic matrix of the phrasal verb cluster 'Leaving')

Table 2 indicates the results of the queries to the corpus necessary to calculate attraction strength of the phrasal verbs under analysis. The value of attraction in the 0-line of Table 2 indicates the attraction threshold $\mathrm{P}($ threshold $)=0,008$ of the Verb+out construction. In other words, the verbs with the value of $\mathrm{P}(\mathrm{a})^{2}>0,008$ are attracted by the construction and if $\mathrm{P}(\mathrm{a})<0,008$ then the construction repels them.

\footnotetext{
${ }^{1}$ The Probability of success, known as one of the key decision factors in Probability Theory, is the ratio of success cases or, in terms of our research, desired occurrences of specific lexical items (in particular, verbs, particles or PhV-constructions) over all outcomes of the same kind derived from the corpus data.

${ }^{2}$ In the paper we call the attraction strength $\mathrm{P}(\mathrm{a})$, the attraction threshold $-\mathrm{P}($ threshold). $\mathrm{P}$ is a capital to not be confused with the p-value in statistics which we conduct to assess the reliability of the findings (Section 2.3, cf. Table 4). We assigned attraction strength to the capital $\mathrm{P}$ since the calculation of attraction is strongly connected to the calculation of the probability of success.
} 


\begin{tabular}{|c|c|c|c|c|c|c|c|}
\hline \multicolumn{3}{|c|}{ Phrasal verb } & \multicolumn{2}{|c|}{ Variable B } & \multicolumn{2}{|r|}{ Variable C } & \multirow{2}{*}{$\begin{array}{c}\text { Variable D } \\
\text { Attraction } \mathbf{P}(\mathbf{a}) \text { of } \\
\text { the verb to the } \\
\text { construction }\end{array}$} \\
\hline № & Verb & $\begin{array}{c}\text { Parti } \\
\text { cle }\end{array}$ & $\begin{array}{l}\text { Occurrence } \\
\text { of verbs }\end{array}$ & $\begin{array}{l}\text { RegEx corpus } \\
\text { query for verbs }\end{array}$ & $\begin{array}{c}\text { Occurrence of the } \\
\text { Verb+[Pron]+OUT } \\
\text { constructions }\end{array}$ & $\begin{array}{c}\text { RegEx corpus } \\
\text { query for phrasal verbs }\end{array}$ & \\
\hline 0 & all verbs & & 15735322 & $\begin{array}{l}\text { VERB }+ \\
\text { deduct modals_vm }\end{array}$ & 125895 & $\begin{array}{l}\text { VERB+ out_rp } \\
\text { add: VERB+_pp out_rp }\end{array}$ & 0,008 \\
\hline 1 & storm & out & 659 & STORM_v & 95 & STORM_v out, STORM_v_pp out & 0,1442 \\
\hline 2 & pull & out & 12921 & PULL_v & 1747 & PULL_v out, PULL_v_pp out & 0,1352 \\
\hline 3 & sally & out & 39 & SALLY_V & 5 & SALLY_v out, SALLY_v_pp out & 0,1282 \\
\hline 4 & step & out & 5520 & STEP_v & 692 & STEP_v out, STEP_v_pp out & 0,1254 \\
\hline 5 & bail & out & 355 & BAIL_v & 143 & BAIL_v out, BAIL_v_pp out & 0,1211 \\
\hline 6 & set & out & 38829 & SET_v & 4608 & SET_v out, SET_v_pp out & 0,1187 \\
\hline 7 & pour & out & 3448 & POUR_v & 391 & POUR_v out, POUR_v_pp out & 0,1134 \\
\hline 8 & spill & out & 1335 & SPILL_v & 151 & SPILL_v out, SPILL_v_pp out & 0,1131 \\
\hline 9 & pop & out & 1956 & POP_v & 154 & POP_v out, POP_v_pp out & 0,0787 \\
\hline 10 & slip & out & 4667 & SLIP_v & 339 & SLIP_v out, SLIP_v_pp out & 0,0726 \\
\hline 11 & duck & out & 581 & DUCK_v & 40 & DUCK_v out, DUCK_v_pp out & 0,0688 \\
\hline 12 & break & out & 17394 & BREAK_v & 1108 & BREAK_v out, BREAK_v_pp out & 0,0637 \\
\hline 13 & check & out & 9355 & CHECK_v & 592 & CHECK_v out, CHECK_v_pp out & 0,0633 \\
\hline 14 & run & out & 38304 & RUN_v & 2139 & RUN_v out, RUN_v_pp out & 0,0558 \\
\hline 15 & strike & out & 7059 & STRIKE_V & 333 & STRIKE_v out, STRIKE_v_pp out & 0,0472 \\
\hline 16 & come & out & 143322 & COME_v & 6435 & COME_v out, COME_v_pp out & 0,0449 \\
\hline 17 & back & out & 4150 & BACK_v & 177 & BACK_v out, BACK_v_pp out & 0,0427 \\
\hline 18 & punch & out & 911 & PUNCH_v & 38 & PUNCH_v out, PUNCH_v_pp out & 0,0417 \\
\hline 20 & fly & out & 8571 & FLY_v & 339 & FLY_v out, FLY_v_pp out & 0,0396 \\
\hline 21 & ship & out & 1562 & SHIP_V & 60 & SHIP_v out, SHIP_v_pp out & 0,0384 \\
\hline 19 & bust & out & 236 & BUST_v & 9 & BUST_v out, BUST_v_pp out & 0,0381 \\
\hline 22 & clear & out & 6094 & CLEAR_v & 230 & CLEAR_v out, CLEAR_v_pp out & 0,0377 \\
\hline 23 & go & out & 236313 & GO_v & 8493 & GO_v out, GO_v_pp out & 0,0359 \\
\hline 24 & $\operatorname{coax}$ & out & 307 & COAX_v & 10 & COAX_v out, COAX_v_pp out & 0,0326 \\
\hline 25 & shoot & out & 7203 & SHOOT_v & 234 & SHOOT_v out, SHOOT_v_pp out & 0,0325 \\
\hline 26 & $\log$ & out & 483 & LOG_v & 14 & LOG_v out, LOG_v_pp out & 0,029 \\
\hline 27 & get & out & 211006 & GET_v & 6010 & GET_v out, GET_v_pp out & 0,0285 \\
\hline 28 & fall & out & 25843 & FALL_v & 714 & FALL_v out, FALL_v _pp out & 0,0276 \\
\hline 29 & move & out & 37290 & MOVE_V & 971 & MOVE_v out, MOVE_v_pp out & 0,026 \\
\hline 30 & draw & out & 21401 & DRAW_v & 519 & DRAW_v out, DRAW_v_pp out & 0,0243 \\
\hline 31 & put & out & 67040 & PUT_v & 1616 & PUT_v out, PUT_v_pp out & 0,0241 \\
\hline 32 & let & out & 34194 & LET_v & 785 & LET_v out, LET_v_pp out & 0,023 \\
\hline 33 & clock & out & 349 & CLOCK_v & 6 & CLOCK_v out, CLOCK_v_pp out & 0,0172 \\
\hline $34:$ & start & out & 39316 & START_v & 491 & START_v out, START_v_pp out & 0,0125 \\
\hline 35 & pile & out & 1012 & PILE_v & 12 & PILE_v out, PILE_v_pp out & 0,0119 \\
\hline 36 & bug & out & 198 & BUG_v & 1 & BUG_v out, BUG_v_pp out & 0,0101 \\
\hline 37 & buy & out & 24741 & BUY_v & 232 & BUY_v out, BUY_v_pp out & 0,0094 \\
\hline 38 & allow & out & 31422 & ALLOW_v & 107 & ALLOW_v out, ALLOW_v_pp out & 0,0034 \\
\hline 39 & light & out & 3365 & LIGHT_v & 11 & LIGHT_v out, LIGHT_v_pp out & 0,0033 \\
\hline 40 & want & out & 86579 & WANT_v & 179 & WANT_v out, WANT_v_pp out & 0,0021 \\
\hline 41 & sign & out & 8782 & SIGN_v & 14 & SIGN_v out, SIGN_v_pp out & 0,0016 \\
\hline 42 & see & out & 181678 & SEE_v & 204 & SEE_v out, SEE_v_pp out & 0,0011 \\
\hline 43 & show & out & 57617 & SHOW_v & 38 & SHOW_v out, SHOW_v_pp out & 0,0007 \\
\hline 44 & encourage & out & 44 & ENCOURAGE_v & 0 & ENCOURAGE_v out, ENCOURAGE_pp out & 0 \\
\hline 45 & breeze & out & 11073 & BREEZE_v & 0 & BREEZE_v out, BREEZE_v_pp out & 0 \\
\hline
\end{tabular}

Table 2: An ordered distribution of 45 phrasal verbs in cluster 'Leaving' according to their attraction strength to the PhV-construction - Variable D

The value of the variable $B$ in the 0 -line indicates the number of instances of all verbs in any form represented in the corpus except all the modals as they do not shape phrasal verbs. The value of the variable $\mathrm{C}$ in the same line indicates the occurrence of the Verb+out phrasal verb constructions with any form of all verbs found in the corpus. Other lines indicate the same values but regarding the number of instances of the particular verb and the variable $\mathrm{D}$ represents the probability of success which is calculated by the formula $\mathrm{P}(\mathrm{a})=\mathrm{C} \div \mathrm{B}$. Comparing this result value of each line $\left(\mathrm{C}_{\mathrm{N}} \div \mathrm{B}_{\mathrm{N}}\right)$ with the 0 -line $\left(\mathrm{C}_{0} \div \mathrm{B}_{0}\right)$, we can get the attraction strength of each tested verb to the Verb+out construction. To represent the data, we grade the phrasal verbs from Table 1 according to their attraction strength ${ }^{3}$ and put them in Table 2.

This distribution of the phrasal verbs to attraction strength reveals three distinct groups:

(a) Group 1 with high attraction strength (coloured green);

(b) Group 2 with moderate attraction strength (coloured white);

(c) Group 3 with low attraction strength (coloured red).

\footnotetext{
${ }^{3}$ Attraction strength is assigned to the comparison of values of the variable D for each verb with the attraction threshold displayed in the 0 -line $\mathrm{P}($ threshold $)=0,008$, which allows us to grade phrasal verbs according to their attraction strength in a descending sequence.
} 
It can be seen in Figure 1 below that the phrasal verbs with the particle out fall into 3 groups:

(a) Group 1 takes the value of attraction strength $\mathrm{P}(\mathrm{a})>0,8$;

(b) Group 2 takes the value of $\mathrm{P}(\mathrm{a})$ which falls in $\mathrm{P}$ (threshold) $\leq \mathrm{P}(\mathrm{a}) \leq 0,8$;

(c) Group 3 takes the value of $\mathrm{P}(\mathrm{a})<\mathrm{P}$ (threshold), where $\mathrm{P}$ (threshold) is at 0,008 marked with the red line in Figure 1.

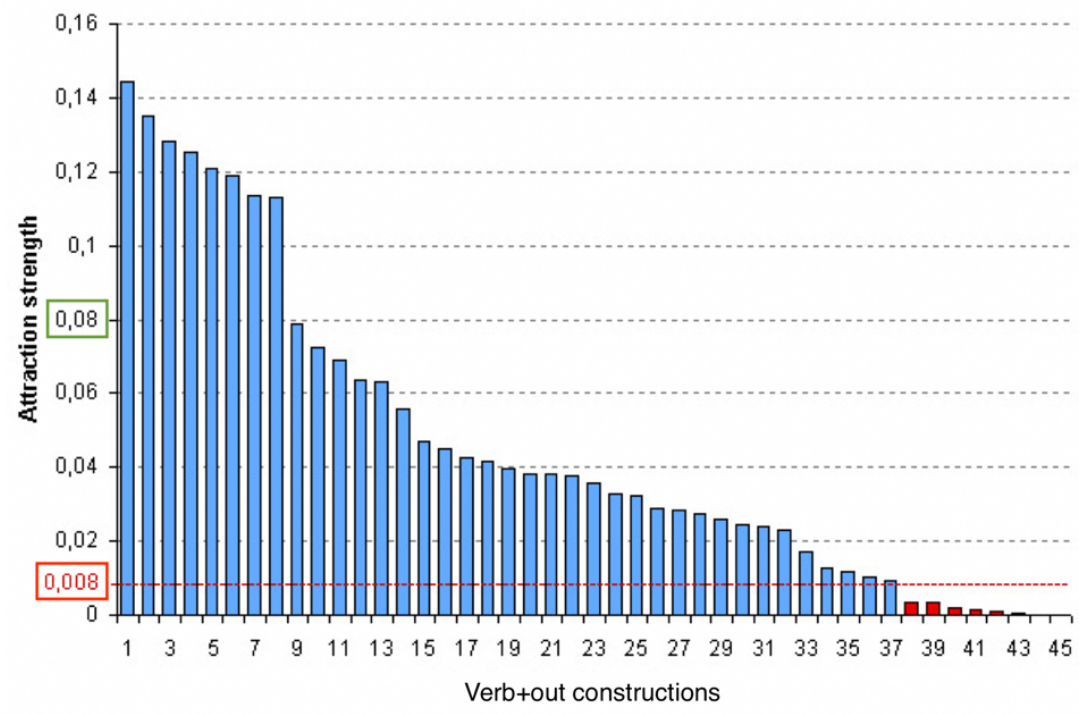

Figure 1: The distribution of the attraction strength of the verbs to the Verb+out construction

According to the attraction strength of the verbs to the Verb+out construction (cf. Figure 1 and Table 2) we regroup the phrasal verbs in Table 1 as follows, in Table 3.

The distribution of the verbs inside Group 2 (coloured white) shown in Table 3 suggests that the verbs with more intensity of strain (the value is 3 ) and manner tend towards Group 1 (coloured green) and the verbs with less intensity of strain (the value is 1) and manner tend towards Group 3 (coloured red). The choice of the intensity value was guided by the experiment on the basis of the behavioral $\mathrm{S} \rightarrow \mathrm{R}$ scheme [9], or the stimulus-reaction scheme, in which the native speaker of English was instructed to evaluate their reaction response for each semantic dimension to a given stimulus - as soon as a construction with a test phrasal verb was uttered by another participant in the experiment.

After the experiment all the collected data were analysed from the viewpoint of the offline introspection [7], assigned with an integer value from 1 to 3 and put in Table 1, which allowed us to arrange the data by the value of specific dimensions such as 'manner' or 'strain' and present them in Table 2.

The preliminary observation of the arranged data leads us to two assumptions:

(i) Phrasal verbs with the manner of action, such as aggressive, forceful, tend to belong to Group 1 , and verbs with the opposite manner, such as friendly, careful, lighthearted, reluctant, respectful, gentle, tend to belong Group 3 in accordance with the attraction strength of the verb to the phrasal verb construction. Thus, the weaker attraction strength to the construction the verb has, the 'softer' the manner of the verb is, while the more attraction strength the verb has, the 'harder' its manner is.

(ii) Phrasal verbs with greater 'Strain' tend to the top of this category revealed by the distribution in Table 3 (Group 1) and phrasal verbs with weak 'Strain' tend to stay at the bottom (Group 3). Thus, the greater attraction strength to the construction the verb has, the greater strain of the action assigned to the verb is.

This inference can be observed in Figure 3 in comparison with Figure 2. The diagram in Figure 2 indicates the behaviour of the semantic dimension 'Strain' at the random distribution (cf. Table 1) of phrasal verbs where we observe no dependence of the semantic dimension on the distribution. 


\begin{tabular}{|c|c|c|c|c|c|c|c|c|c|c|c|}
\hline \multicolumn{2}{|c|}{ Phrasal verb } & \multicolumn{10}{|c|}{ Semantic dimensions (aspects of action) } \\
\hline Verb & $\begin{array}{c}\text { Parti } \\
\text { cle }\end{array}$ & Manner & $\begin{array}{l}\text { Strain } \\
\text { 1- low } \\
\text { 2- avr, } \\
\text { 3- high }\end{array}$ & $\begin{array}{l}\text { Speed } \\
\text { 1- low } \\
\text { 2- avr. } \\
\text { 3- high }\end{array}$ & $\begin{array}{l}\text { Duration } \\
\text { 1- low } \\
\text { 2- avr. } \\
\text { 3- high }\end{array}$ & $\begin{array}{l}\text { Intention } \\
\text { 1- unint. } \\
\text { 2- hesitat } \\
\text { 3- intent. }\end{array}$ & \begin{tabular}{l}
\multicolumn{1}{c}{ Morality } \\
1- immoral \\
2- suspect \\
3- moral
\end{tabular} & \begin{tabular}{|l|} 
Physicality \\
1- nearly 0 \\
2- limited \\
3- real
\end{tabular} & \begin{tabular}{|l|} 
Reversibility \\
1- irrevers. \\
2- partially \\
3- reversable
\end{tabular} & $\begin{array}{l}\text { Toolability } \\
\text { 1- toolless } \\
\text { 2- auxilary } \\
\text { 3- toolfull }\end{array}$ & $\begin{array}{l}\text { Agents } \\
\text { 1- one } \\
\text { 2- a few } \\
\text { 3- a lot }\end{array}$ \\
\hline storm & out & Agressive & 3 & 1 & 2 & 3 & 1 & 3 & 1 & 1 & 1 \\
\hline pull & out & Controlled & 3 & 1 & 2 & 3 & 2 & 1 & 3 & 1 & 1 \\
\hline sally & out & Agressive & 3 & 3 & 1 & 3 & 2 & 3 & 1 & 1 & 3 \\
\hline step & out & Orderly & 2 & 3 & 2 & 1 & 2 & 3 & 3 & 1 & 1 \\
\hline bail & out & Forceful & 3 & 3 & 1 & 3 & 3 & 3 & 1 & 3 & 1 \\
\hline set & out & Orderly & 1 & 3 & 1 & 3 & 2 & 3 & 3 & 1 & 1 \\
\hline pour & out & Controlled & 2 & 2 & 2 & 3 & 2 & 3 & 3 & 1 & 3 \\
\hline spill & out & Uncontrolled & 3 & 2 & 3 & 1 & 2 & 3 & 1 & 1 & 3 \\
\hline pop & out & \begin{tabular}{|l|} 
Sudden \\
\end{tabular} & 2 & 3 & 1 & 1 & 2 & 3 & 3 & 1 & 3 \\
\hline slip & out & Secretive & 2 & 1 & 2 & 3 & 1 & 3 & 3 & 1 & 1 \\
\hline duck & out & Secretive & 3 & 3 & 1 & 3 & 1 & 1 & 1 & 1 & 1 \\
\hline break & out & Challenging & 3 & 3 & 1 & 3 & 1 & 1 & 3 & 2 & 1 \\
\hline check & out & Orderly & 1 & 3 & 1 & 3 & 3 & 2 & 3 & 3 & 1 \\
\hline run & out & Desperate & 3 & 3 & 1 & 3 & 1 & 3 & 2 & 1 & 1 \\
\hline strike & out & Decisive & 2 & 3 & 1 & 3 & 2 & 2 & 3 & 3 & 1 \\
\hline come & out & Neutral & 2 & 2 & 2 & 3 & 2 & 3 & 3 & 1 & 1 \\
\hline back & out & Renegade & 2 & 3 & 3 & 3 & 1 & 1 & 2 & 2 & 1 \\
\hline punch & out & Desperate & 3 & 1 & 2 & 3 & 2 & 2 & 1 & 1 & 1 \\
\hline fly & out & Forceful & 3 & 3 & 1 & 2 & 2 & 3 & 3 & 1 & 1 \\
\hline ship & out & Specific & 1 & 1 & 2 & 3 & 2 & 3 & 1 & 3 & 1 \\
\hline bust & out & Secretive & 3 & 3 & 1 & 3 & 1 & 3 & 1 & 2 & 1 \\
\hline clear & out & Forceful & 2 & 3 & 1 & 3 & 2 & 3 & 3 & 2 & 1 \\
\hline go & out & Neutral & 2 & 3 & 2 & 3 & 2 & 3 & 3 & 1 & 1 \\
\hline coax & out & Careful & 1 & 1 & 3 & 3 & 2 & 3 & 3 & 1 & 1 \\
\hline shoot & out & Sudden & 3 & 3 & 1 & 2 & 2 & 3 & 3 & 1 & 1 \\
\hline $\log$ & out & Orderly & 1 & 3 & 1 & 3 & 2 & 1 & 3 & 3 & 1 \\
\hline get & out & Neutral & 2 & 3 & 2 & 3 & 2 & 1 & 3 & 1 & 1 \\
\hline fall & out & Accidental & 1 & 3 & 1 & 1 & 2 & 3 & 3 & 1 & 1 \\
\hline move & out & Orderly & 1 & 1 & 3 & 3 & 2 & 3 & 3 & 1 & 1 \\
\hline draw & out & Careful & 1 & 1 & 3 & 3 & 2 & 3 & 3 & 1 & 1 \\
\hline put & out & Forceful & 3 & 3 & 1 & 3 & 1 & 3 & 3 & 1 & 1 \\
\hline let & out & Controlled & 1 & 3 & 1 & 2 & 2 & 3 & 3 & 1 & 1 \\
\hline clock & out & \begin{tabular}{|l|} 
Orderly \\
\end{tabular} & 1 & 3 & 1 & 3 & 3 & 2 & 3 & 3 & 1 \\
\hline start & out & Orderly & 1 & 3 & 2 & 3 & 2 & 2 & 3 & 1 & 1 \\
\hline pile & out & \begin{tabular}{|l|} 
Disorderly \\
\end{tabular} & 3 & 2 & 2 & 2 & 2 & 3 & 3 & 1 & 3 \\
\hline bug & out & Disorderly & 3 & 3 & 1 & 3 & 2 & 3 & 1 & 1 & 1 \\
\hline buy & out & Gentle force & 2 & 3 & 3 & 3 & 2 & 1 & 1 & 2 & 1 \\
\hline allow & out & Controlled & 1 & 3 & 1 & 2 & 2 & 3 & 3 & 1 & 1 \\
\hline light & out & Disorderly & 2 & 3 & 1 & 3 & 2 & 3 & 3 & 1 & 1 \\
\hline want & out & Reluctant & 1 & 1 & 2 & 3 & 2 & 1 & 3 & 1 & 1 \\
\hline sign & out & Orderly & 1 & 1 & 1 & 3 & 2 & 1 & 3 & 3 & 1 \\
\hline see & out & Respectful & 1 & 2 & 2 & 3 & 3 & 3 & 1 & 1 & 1 \\
\hline show & out & Friendly & 1 & 2 & 2 & 3 & 3 & 3 & 1 & 1 & 1 \\
\hline encourage & out & Careful & 1 & 1 & 3 & 3 & 2 & 3 & 3 & 1 & 1 \\
\hline breeze & out & Lightharted & 1 & 3 & 1 & 3 & 2 & 3 & 3 & 1 & 1 \\
\hline
\end{tabular}

Table 3: An ordered distribution of the phrasal verbs according to their attraction strength and the intensity of their semantic dimensions

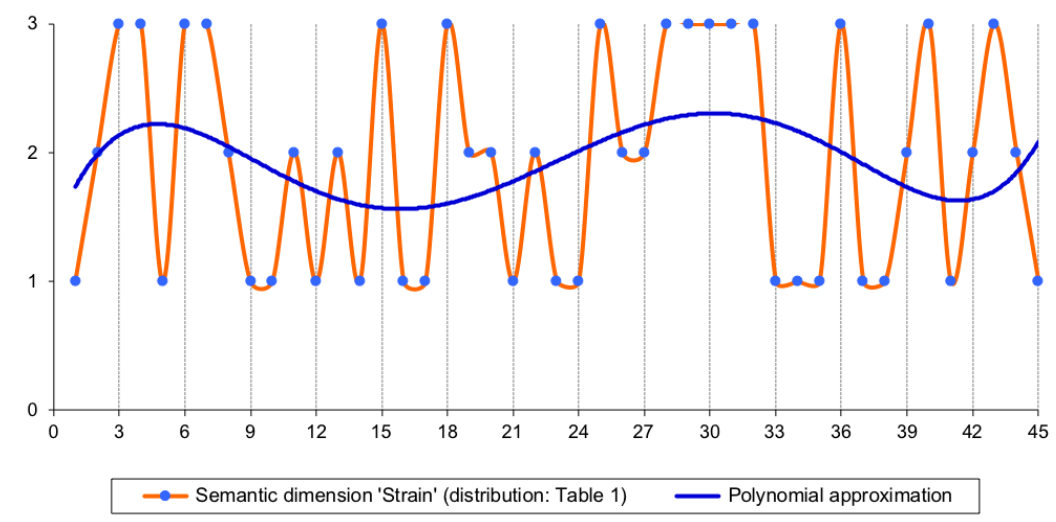

Figure 2: A random distribution of empirical data of the semantic dimension 'Strain' of 45 test phrasal verbs according to Table 1 . 


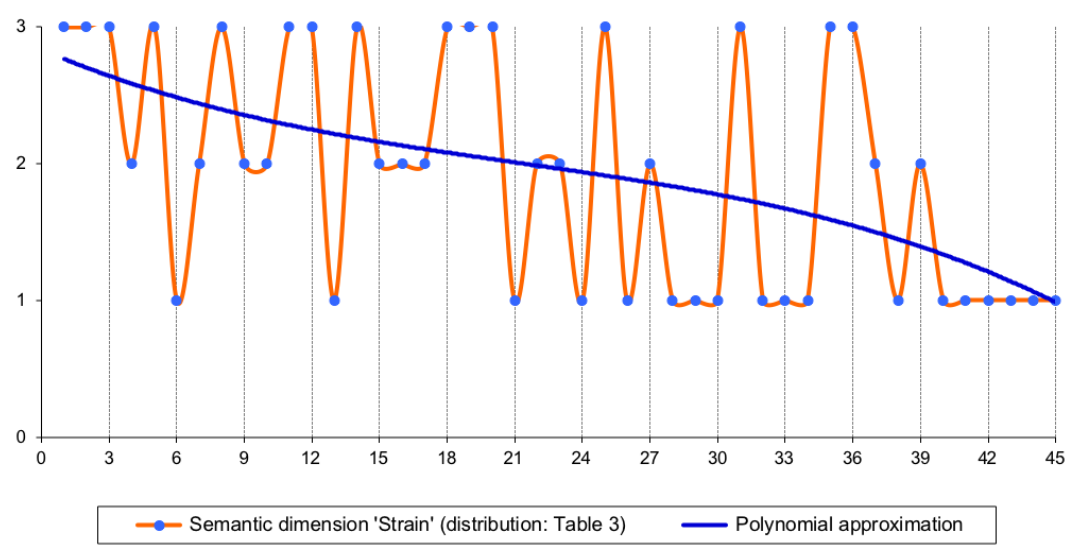

Figure 3: An ordered distribution of empirical data of the semantic dimension 'Strain' of 45 test phrasal verbs according to Table 3 .

An overlaid trend line (coloured blue) shows the behaviour pattern of phrasal verbs regarding the semantic dimension of action 'Strain' which can be easily seen if we apply polynomial approximation known as the easiest conventional method to generalise empirical result data.

\subsection{Attraction of the particle OUT to the Verb+out construction}

The value of attraction of the particle can be measured by using collexeme analysis based on the corpus data. According to Gries's [2] method of defining attraction strength, the threshold value of particle attraction was calculated $(0.2742)$ which further should be compared with the ratio of occurrences of the out in the corpus $(0.7810)$ which is 3 times as high as the threshold value. It led us to conclusion that the particle is strongly attracted to the verbal form. This level of attraction, as we can see, is strong enough to let us consider most cases of 'Verb+out' as an integral unit. As a result, we get the set of values of attraction strength of the particle out to the corresponding verbal construction.

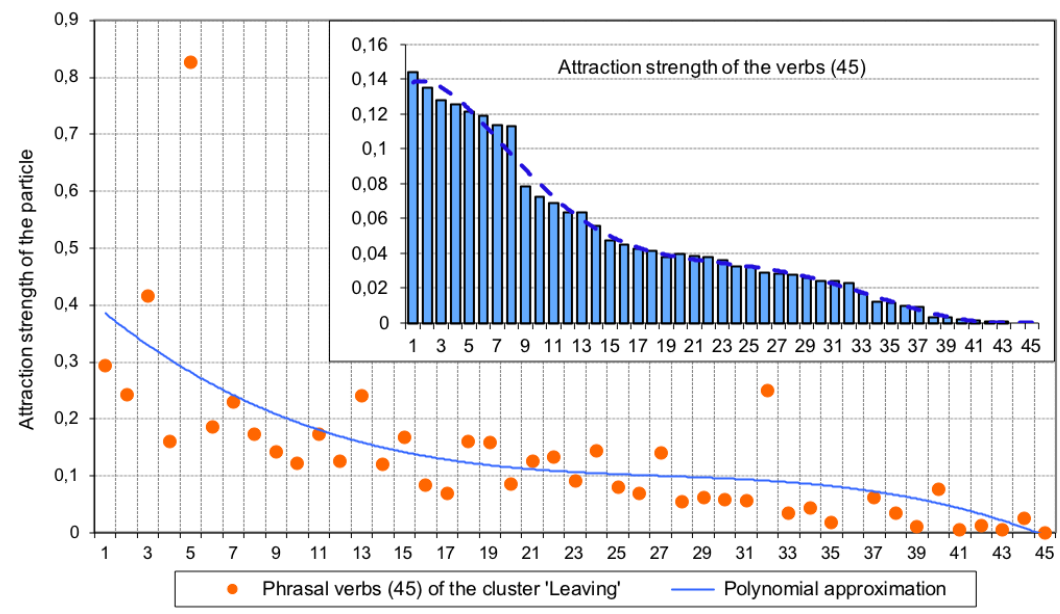

Figure 4: The particle attraction strength to the Verb+out construction

The diagram in Figure 4 shows the distribution of the particle out attraction strength to the construction 'Verb+out', where the polynomial approximate curve indicates the same trend as shown above (cf. Figure 1) which confirms the attraction force between the particle out and the verb. In its turn, it illustrates a steady correlation between the particle and the verb as if they function as an indivisible unit. The trends of mutual attraction between the verb and the particle also coincide with the trend of the semantic dimension 'Strain' of the corresponding phrasal verbs (cf. Figure 3). These concordant trends make it 
possible to assume that the semantic dimensions 'strain', 'manner' and the attraction strength also become concordant.

In fact, having graded the result data according to the attraction strength of the particle out, in Figure 5 we show the correlation between the attraction of the particle out to each of the 45 tested phrasal verbs and the change of 'Strain' which is their semantic dimension of action. This correlation is also confirmed by the correlation matrix (cf. Table 4) in which Pearson correlation coefficient (PCC) takes the value of 0.464 for the verb and 0.422 for the particle in respect of the correlation between the attraction level and the change of the semantic dimension 'strain' of the tested phrasal verbs. The PCC values of 0.337 and 0.353 account for the correlation between the semantic change of manner and the level of attraction between the verb and the particle respectively, which indicates the positive leaner correlations in either case.

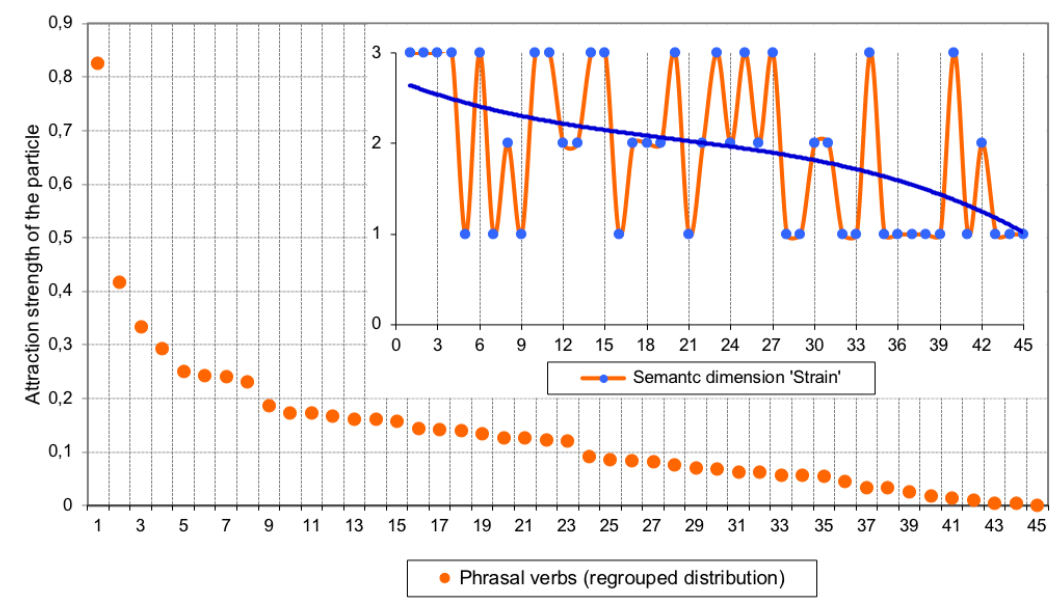

Figure 5: The correlation between the attraction strength of the particle to the $\mathrm{PhV}$-construction and the semantic dimension 'Strain' of the tested phrasal verbs

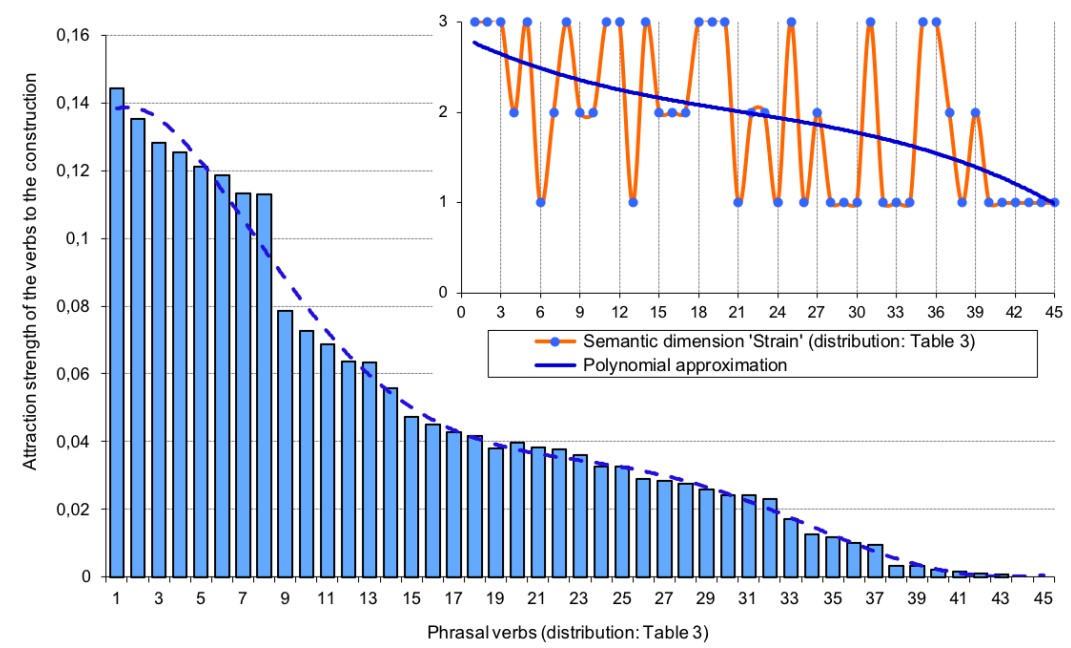

Figure 6: The correlation between the attraction strength of the tested phrasal verbs to the PhV-construction and their semantic dimension 'Strain'

The statistical significance check p-values of $0.001<0.05$ (for the verb) and $0.004<0.05$ (for the particle) towards the correlation between the attraction level and the semantic change of the aspect 'Strain' along with the p-values of 0,024 $<0.05$ (for the verb) and $0.017<0.05$ (for the particle) towards the correlation between the attraction level and the semantic change of manner suggest that attraction features the change of certain semantic dimensions of phrasal verbs, in particular 'strain' and manner, where 'strain' stands for the amount of energy involved in performing an action. 


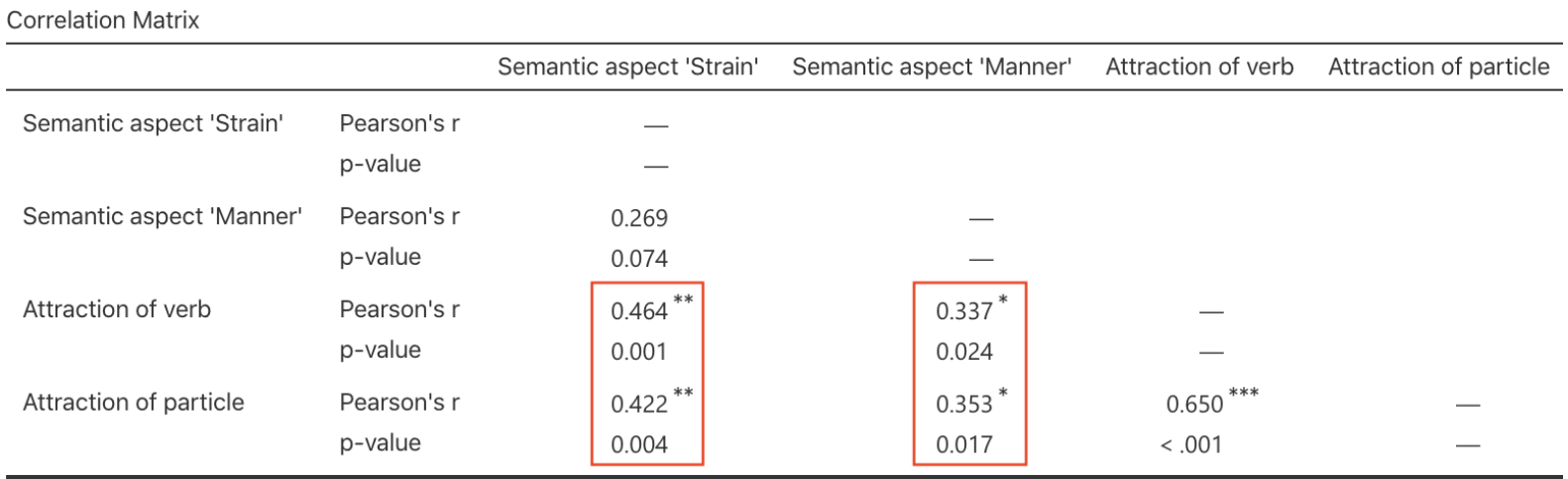

Note. ${ }^{*} \mathrm{p}<.05,{ }^{* *} \mathrm{p}<.01,{ }^{* * *} \mathrm{p}<.001$

Table 4: The correlation matrix of attraction and semantic variables of the tested phrasal verbs (processed by Jamovi statistical software platform [12])

Evidently, all the considered p-values are less than the conventional statistical significance threshold $\mathrm{p}=0.05$ and in case of the semantic dimension 'strain' the p-values are less than the 0.01-threshold, which suggests that the correlations are statistically significant and confirms the hypothesis.

Whereas the distribution of the value of the semantic dimension 'Strain' is also affected by the particle, which can be seen from the comparison of the built-in diagrams in Figures 5 and 6, the tendency remains the same keeping agreement with the data distributions of the verbs and the particle attraction strength. These are shown in the diagrams in Figures 1 and 4 where their interdependence can be easily traced, a fact that demonstrates a verb-particle behaviour dependence. This behaviour pattern is represented in Figure 7.

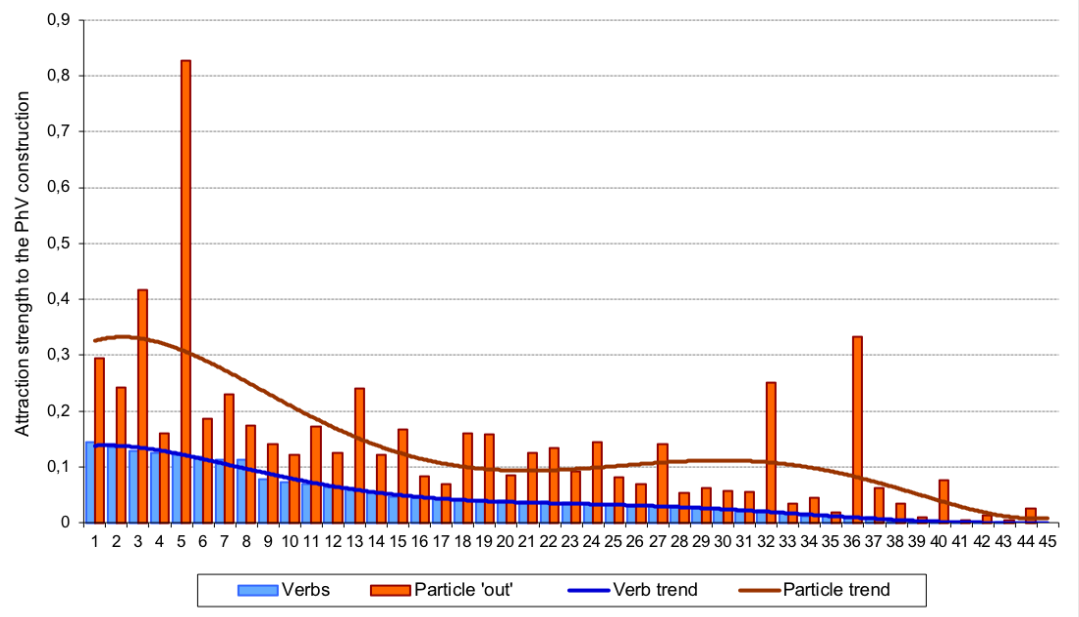

Figure 7: The correlation between the attraction strengths of the verb and the particle

The results suggest coordination between the particle, verb and some semantic dimensions (for example, manner, strain) that shapes an indivisible specific constructional unity allowing new verbs which exceed the attraction threshold set by the construction into the corresponding slot of the construction. These verbs provide for the specification of the meaning that corresponds to the meaning of the general construction which, in its turn, obtains this specification from the situation to which it is eventually linked. If the situation of communication has such specifications, that is, we deal with a specific form of the situation, it forces the construction into changing, attracting new verbs which are capable of conforming to the meaning of the situation in each specific case. This constructional unity can be called a phrasal verb construction (PhV construction). It seems reasonable to single out a specific phrasal verb construction that can retain its form and hold the general phrasal verb construction as an embedded structure which has to acquire a new form whenever the situation changes, for example (cf. Table 5). 
Given the possibility of measuring attraction we can arrange phrasal verbs in new clusters of synonyms according to their level of attraction strength that defines the level of their stability in constructions. The higher level of attraction the verb has, the more stable the verb is. Then such constructions are also more stable, which also accounts for their indivisibility, and can be freely understood by the listener even if they are entirely new.

\begin{tabular}{clcl}
$\begin{array}{c}\text { New PhVs based } \\
\text { on analogy }\end{array}$ & $\begin{array}{c}\text { General PhV con- } \\
\text { struction }\end{array}$ & $\begin{array}{c}\text { Semantic } \\
\text { modification }\end{array}$ & \multicolumn{1}{c}{ Specific PhV construction } \\
\hline to coffee up & $\begin{array}{c}\text { X bucks Y up } \\
\text { X perks Y up }\end{array}$ & $\begin{array}{c}\text { of manner: } \\
\text { using coffee }\end{array}$ & $\begin{array}{l}\text { I had to work the night shift so I cof- } \\
\text { feed myself up numerous times. }\end{array}$ \\
\hline to tea down & X calms Y down & $\begin{array}{c}\text { of manner: } \\
\text { using tea }\end{array}$ & $\begin{array}{l}\text { He seems so keyed up, we can try to } \\
\text { tea him down. }\end{array}$ \\
\hline to burn by & X comes by [prep] Y & $\begin{array}{c}\text { of manner: } \\
\text { quicker }\end{array}$ & $\begin{array}{l}\text { Although she loves her, she rarely } \\
\text { burns by at her mother's. }\end{array}$ \\
\hline to spirit down & X brings Y down & $\begin{array}{c}\text { of result: } \\
\text { less animated }\end{array}$ & $\begin{array}{l}\text { He was excited about new project. We } \\
\text { had to spirit him down before the in- } \\
\text { vestors came. }\end{array}$ \\
\hline to fall near & X comes near [prep] Y & $\begin{array}{c}\text { of manner: } \\
\text { unexpectedly } \\
\text { to get to know }\end{array}$ & $\begin{array}{l}\text { He offered me a senior post soon after } \\
\text { we had fallen near at the congress. }\end{array}$ \\
\hline
\end{tabular}

Table 5: Attraction of new members of the PhV construction: semantic conformation of the general $\mathrm{PhV}$ construction to the meaning of the specific $\mathrm{PhV}$ construction

Constituting a PhV construction the particle and the verb hold mutual attraction to a Verb+Particle pattern forming a PhV lexical unit which steadily correlates with certain semantic dimensions disclosing the semantic behavioural pattern of the unit.

\section{Conclusion}

In the present paper we view phrasal verbs as lexico-grammatical constructions in line with the theory of Construction Grammar. Given this concept, the results of our investigation led us to believe that verbparticle attraction contributes significantly to shaping the set of semantic dimensions such as 'strain' and 'manner' of the phrasal verb, which could be expressed through the level of verb-particle attraction strength and subsequently digitalised. It allows us to represent the semantics of phrasal verbs through the semantic matrix, in which the values correspond to the verb-particle attraction levels. The results suggest the possibility of classifying phrasal verbs by verb-particle attraction levels, which play an important role in phrasal verb production.

Depending on the level of verb-particle attraction strength a new participant may be accepted to fill in the corresponding slot of the construction, which gives rise to a new phrasal verb. It allows us to categorise PhVs according to the attraction level and recognize their PhV-patterns.

Following the results of the comparison of the attraction indexes of both verbs and particles, it was demonstrated that the particle is much more stable than the verb in a phrasal verb construction, which also confirms the typology of English as a satellite-framed language [6] from the viewpoint of Corpus Linguistics. This fact enables us to conclude that the verb takes an open position in the construction, and can be replaced by a new verb which is attracted or 'invited' into the construction on terms of sufficient attraction strength exceeding the attraction threshold or otherwise repelled due to semantic restrictions. Thus, the new participants which may be accepted by the construction are verbs. As a consequence of this acceptance any new participant shapes a new phrasal verb. That is to say, attraction acts between linguistic constituents of the construction pulling in more and more new participants (verbs) and shaping more and more phrasal verbs according to the same PhV pattern.

The results also indicated the presence of coordination between verb-particle attraction and the semantic dimensions 'manner' and 'strain' involved in the description of the action or motion event [5], revealing the strength of attraction which admits new verbs into the construction triggering the corresponding semantic change of the meaning of the construction. 


\section{References}

[1] Golubkova E.E., Trubochkin A.V. (2019), Phrasal Verbs from the Viewpoint of Construction Grammar in Modern English [Frazovye glagoly kak grammaticheskie konstrukcii (na materiale anglijskogo jazyka)], Cognitive Studies of Language. Integrative Processes in Cognitive Linguistics: Papers of International Congress on Cognitive Linguistics. May, 16-18, 2019 [Kognitivnye issledovanija jazyka. Integrativnye processy v kognitivnoj lingvistike: Materialy Mezhdunarodnogo kongressa po kognitivnoĭ lingvistike 16-18 maja 2019 goda], Vol. 37, pp. 604-608. Access mode: https:/nnov.hse.ru/mirror/pubs/share/direct/266828046.

[2] Gries Stefan, Stefanowitsch Anatol. Extending Collostructional Analysis: A Corpus-based Perspective on 'Alternations' // International Journal of Corpus Linguistics. - 2004. — Vol. 9 (1), P. 97-129. Access mode: doi.org/10.1075/ijcl.9.1.06gri.

[3] Langacker Ronald. Construction Grammars: cognitive, radical and less so. // Paper presented at the international Cognitive Linguistics Conference. - Logroño, 2003.

[4] Rakhilina E.V. (2010), Construction Linguistics [Lingvistika konstrukcij], Moscow : Azbukovnik, pp. 3539. Access mode: http://rakhilina.ru/files/rakh_lingconst.pdf.

[5] Talmy Leonard. Path to Realization: A Typology of Event Conflation // Proceedings of the Seventeenth Annual Meeting of the BLS. - 1991. — P. 480-519. Access mode: doi.org/10.3765/bls.v17i0.1620.

[6] Talmy Leonard. Toward a cognitive semantics. - Cambridge, MA : MIT Press, 2000. — Vol. 2.

[7] Talmy Leonard. Introspection as a Methodology in Linguistics // Proceedings of the Tenth International Cognitive Linguistic Conference. - Buffalo, USA, 2007. - P. 1-20. Access mode: http://www.acsu.buffalo.edu/ talmy/talmyweb/Handouts/introspection2.pdf.

[8] Taylor Andrew. Longman Phrasal Verb Dictionary Paper (Phrasal Verb Dictionary). — Harlow : Pearson Education Limited, 2000. — P. 35-36. Access mode: www.pearson.com/english/catalogue/dictionaries/browse/specialised/phrasal-verbs-dictionary.html.

[9] Watson John. Behaviorism (revised ed.). — Chicago, USA : University of Chicago Press, 1930 (1924). Access mode: OCLC https://www.worldcat.org/title/behaviorism/oclc/3124756, https://archive.org/details/behaviorism032636mbp/page/n259/mode/2up.

\section{Corpora}

[10] BNC World. The British National Corpus: 100 million words. — Oxford University Computing Services on behalf of the BNC Consortium, 2001. — version 2. Access mode: http://www.natcorp.ox.ac.uk/ [electronic resource].

[11] Davies, Mark. The iWEB Corpus: The 14 Billion Word Web Corpus. — Provo, UT : Brigham Young University, 2018. Access mode: https://www.english-corpora.org/iweb/ [electronic resource].

\section{Software}

[12] Jamovi. The Jamovi project. Open statistical platform. - Sydney, Australia, 2020. — version 1.2.17.0. Access mode: https://www.jamovi.org/ [software package]. 